\title{
Fortifying boundaries
}

- The "how and why" of the Finnish media and countermedia from 2014 to 2018

\author{
OLLI SEURI \\ Tampere University \\ PIHLA TOIVANEN \\ University of Helsinki
}

\section{Abstract}

This article examines how recent changes in the hybrid media environment have led media actors to define the "how and why" of their practices. We consider the discussion on the differences and similarities surrounding both the legacy media, and newcomers such as countermedia, to be part of journalism's boundary work: the ongoing, yet temporally fickle process of marking the boundaries between journalism and non-journalism. We demonstrate how both legacy and countermedia actors drew boundaries through vocabulary, institutional reflection, demarcation practices, and ethos. While the Finnish media underlined its institutional autonomy and dominance by defending the social good of journalism and dubbing countermedia as fake media, countermedia actor $M V$-lehti drew its own boundaries by ridiculing media professionals, media institutions, and journalists. Our findings illustrate how these actors consistently asserted the flawed ideological foundations of "the other," with the consequence that boundaries have become fortified, rather than crossed or blurred.

\section{KEYWORDS}

alternative media, boundary work, countermedia, fake news, hybrid media system, journalism, media work 


\section{Preface}

Problematic online sites, sometimes dismissively addressed as purveyors of fake news, have become ubiquitous in the Western mediascape, creating a backbone of fringe media ecosystems (Välimäki et al., 2021) largely coalescing around the right (see Haller et al., 2020; Holt, 2020). Whilst these countermedia websites or actors differ across the spectrum of media culture, they do share some common characteristics. Arguably, they can be described as pseudojournalism (see Schudson, 2020, p. 13; Kovach \& Rosenstiel, 2014, p. 18) on the basis that they imitate the form and appearance of traditional journalistic media without conforming to its ethical standards and practices. The rise of these sites, and the mainstream interest in them, have occurred in conjunction with discussions on both fake news and disinformation, and have consequently been alleged, and found, to have disseminated false information (see Mourão \& Robertson, 2019; Ylä-Anttila, 2017, p. 46).

These changes in the media environment have led journalistic ranks to strengthen their reputations by reaffirming their importance to the audience and society. Most notably in the US, The Washington Post introduced its slogan "Democracy Dies in Darkness" in 2017, and The New York Times launched a "Truth is Essential" campaign in 2020. In Finland, the editors-in-chief of most legacy media outlets made a statement in March 2016 to promote "reliable media," whilst two years later, the Finnish Council for Mass Media (CMM) launched a campaign for "accountable journalism." These initiatives underline how the discussion on fake news (including the emergence of countermedia) has been a so-called "critical incident" (Zelizer, 1992), which has led journalists to reconsider "the hows and whys of journalistic practice." In so doing, they have been driven to reflect on their values by reasserting the normative boundaries of their profession and practices.

We argue that the conversation around insulating the differences between the legacy media and the newcomer is consistent with the recurring fabrication of boundaries within and between journalism: in this case, the process of marking boundaries between journalism and non-journalism. Carlson (2016) writes that boundaries are powerful social constructions that affect the allotment of "epistemic authority," denoting knowledge practices accepted by others 
as legitimate. The scholarship on journalism's boundary work often cites the work of Gieryn $(1999 ; 1983)$ on the boundaries of science. Even though there are notable differences between science and journalism, Gieryn (1983) persuasively captures the discursive means through which boundaries of social practices arise and face contestation (see Carlson, 2016). Gieryn (1983) notes how the construction of boundaries has become useful for scientist's professional goals such as the acquisition of intellectual authority and protecting the autonomy of scientific research. Following this, we will show how journalism's current boundary work is intrinsically related to a critical incident and embedded in journalism as a profession.

The research question in this article is: what kind of boundary work was stimulated by the fake news phenomenon and the new countermedia websites in Finnish media between 2014 and 2018? We address this question empirically, by analyzing how selected Finnish media reacted to the evolution of countermedia actors, and how the most prominent countermedia, $M V$-lehti ${ }^{l}$, positioned itself with regard to journalism and traditional mass media outlets. We focus on a five-year period, which captures the period before and after 2016, the year which saw the popularization of fake news (Quandt et al., 2019). Finland offers an intriguing perspective on this period, as the most important of the countermedia websites emerged before and during the European-wide refugee crisis in 2015. In particular, MV-lehti (MV being the equivalent of the expression "WTF" in English) gained considerable traction. According to research carried out by Finnish newspaper Helsingin Sanomat (HS 18.12.2018), they recorded 18 million views in January 2016 alone, beating the second biggest daily newspaper Aamulehti with its online reach.

The theoretical basis of our analysis is established below, before contextually relating it to the temporal and qualitative features of boundary work and showing how fake news as a concept grew in popularity in the Finnish mediasphere within the chosen timespan. The "hows and whys" of both legacy and countermedia are explored to explain the similarities and differences of their boundary work. Finally, we outline the main findings of our empirical research, showing its relevance to the extant scholarship, and wider discussions, on the boundaries of journalism, countermedia, and fake news in a hybridized media system. 


\section{Theoretical context}

\section{Fake news and countermedia}

This article explores the popular use of the concept fake news and how it was used to describe and analyze changes in the mediasphere, politics, and democracy in Finland. This means we are attentive to the use of particular Finnish terms related to the fake news phenomenon, and the ways they were attached to countermedia. While fake news is not in itself a new phenomenon - the term had already been used by the late 1800s to refer to made up or false news (Mohr, 2019) - it became a topic of global interest and debate with the increased reverberation of social media, especially surrounding the 2016 US presidential elections and Brexit (see Gelfert, 2018). More recently, the range of phenomena linked to fake news have included, inter alia: myriad forms of junk news or false information disguised as news; disinformation campaigns and computational propaganda; populist efforts to discredit legacy media by calling them fake news; and post-truth politics (see Aral, 2020, pp. 26-38; Howard, 2020, pp. 86-87; Bradshaw, 2019).

Notions of fake news then overlap markedly with other information disorders and, consequently, there is no singular definition for it (see Farkas \& Schou, 2020, pp. 53-55; Egelhofer \& Lecheler, 2019; Tandoc et al., 2018). In mainstream discussions certain non-mainstream websites have also been clumsily categorized as fake news, prompting scholars to generate more appropriate formulations to capture variant actors, whose content is not all fake, as in "made up" (Ylä-Anttila et al., 2019). In contesting this narrative, these websites have been further defined as countermedia (see Toivanen et al., 2021; Hopp et al., 2020; Ylä-Anttila et al., 2019), alternative media (see Nygaard, 2020; Schulze, 2020; Holt, 2018), and hyperpartisan media (see Rae, 2020; Heft et al., 2020). These definitions also work as distinctions to more traditional partisan media (Levendusky, 2013) and populist media (Norocel et al., 2020).

We note that the term 'fake news' has become something that people increasingly want to avoid because it has become a disputed, politicized, and even "an infected concept" (Holt, 2020, p. 59). In spite of this, we understand the conjunction and importance of 
fake news and countermedia as reflective of three interrelated factors that shape our analysis. First, fake news as a phenomenon is a symptom of a wider systemic challenge around the value and credibility of information in society (Beckett, 2017). Secondly, fake news and countermedia actors have already intervened with journalism's privileged role as a mediator, analyst, watchdog of politics (Heikkilä \& Väliverronen, 2019), or, as Holt (2020, p. 4) describes it, "an expression of the vulnerability of journalism in a globalized and digitized world." In this sense, traditional journalistic media has received a wake-up call and a test to show its worth and distinctiveness as a form of knowledge and social resource (Schudson, 2003). Thirdly, the fake news phenomenon writ large has been a relevant context in which to analyze the changes in the hybrid media environment during the period we are concerned with.

\section{Blurring boundaries as a feature of journalism and the hybrid media system}

The diffusion and rapid evolution of new communication technologies have already reshaped the media: first with the switch from analog to digital, secondly the rise of the social web, and thirdly the dominance of mobile technologies (Bell et al., 2017). Digital platforms have taken an increasingly important role in journalism by shaping the way people communicate and mediating the interaction between actors. It is certainly arguable, that the changes in both the media environment and the landscape of news, have amplified reconsiderations and rearticulations of what journalism is, and what its role in a functioning democracy should be. As Deuze (2019) argues, we have found ourselves "in a wonderful quagmire," where "journalism remains the same yet the conditions under which it is practiced have not only changed considerably, they are in permanent flux."

In attempting to bring order and clarity to this 'state of flux', Chadwick (2017) articulates the notion of hybridity. He notes that boundary drawing, boundary blurring, and boundary crossing are qualities of the hybrid media system. For instance, it is increasingly difficult to distinguish some political reporting in blogs from political journalism or to discern the contributions of various interlopers who populate newsrooms' digital practices. The journalistic community, 
and its challengers and adversaries, are in a constant discussion of what should be included inside the increasingly blurred journalistic boundaries. This is the primary puzzle. What counts as journalism and who counts as a journalist (Carlson, 2015)? However, below the surface there are many other related questions from ethics and practices to the means of interaction with stakeholders such as audiences, sources, and other non-journalistic actors.

In light of this, we argue that new digital publishers - including countermedia - have challenged, and will challenge, journalism in the short to medium term. Changes already seen in the media system indicate that changes in the context of journalism do shape its understanding and social locus. The rise of social media and digitalization, resulting in more fluid, decentralized, flexible, networked, and individualized modes of work (Deuze \& Witschge, 2018), as well as the development of virality-fueled newcomers such as Buzzfeed (Tandoc, 2018), is also linked to the myriad of algorithmically-induced countermedia and junk news (see Bradshaw, 2019). So, blurring boundaries can be a feature of the hybrid media system, but it is also a feature of journalism itself. Deuze (2019) approaches hybridity by observing the messiness intrinsic to journalism and how its varied cultural practices are embedded within a complex social landscape; it is a constantly shifting denotation applied differently depending on context (Carlson, 2015).

Our interest is on both traditional and countermedia and the boundary work which stems from their engagement and dueling. The extant research shows how traditional media, in times of media instability, commonly uses their normative standards and ethical principles to distinguish between insiders and outsiders (Singer, 2015). Therefore, it is unsurprising that the combination of fake news and new online publishers has witnessed the forced reconsideration, rearticulation, and reinforcement of boundaries in the form of new legislation and revised ethical standards (see Tandoc et al., 2019; Tandoc \& Jenkins, 2018). Evidently there is an intrinsic tension between the ideological claims of journalists and how they live up to those ideals, or "the spirit that is expressed in practice" (Carey, 1997). Arguably, this explains why transparency is seen as an emerging ideal that configures the boundaries of journalism, possibly surpassing its ideological commitment to control (Hermida, 2015; Singer, 2015). 


\section{Research material and methods}

The research material employed here was collected both from traditional Finnish legacy media outlets and MV-lehti. To get a comprehensive picture of the mass media discussion in Finland we have constructed datasets from four different media: 1) the Finnish news agency STT, 2) the main national daily newspaper Helsingin Sanomat (HS), 3) web-based articles in the Finnish public service broadcaster Yle, and 4) one of the two main Finnish daily tabloids Iltalehti (IL). Together, they represent major segments of the Finnish mass media system: a news agency, a daily newspaper, a public broadcaster, and a tabloid. The original datasets include all articles from each media from the beginning of 2014 to the end of 2018.

This was supplemented with 37477 stories scraped from $M V$-lehti between 25.08.2014 and 03.03.2018 and includes all stories found on the website in March 2018. MV-lehti (MV) serves as a legitimate counterpart to the traditional media, publishing its original stories along with texts from other outlets. It also circulates social media and blog posts from different actors inside and outside the right-wing media ecosystem. Throughout the research period, it functioned as a sort of "alternative umbrella," although its radical right-wing and anti-immigrant tendencies became more pronounced over time.

In creating our dataset we downsampled the data with two rounds of forming search keywords. In the preparatory search in the first round, 28 search clauses for the legacy media outlets and 9 search clauses for $M V$-lehti were used. The keywords for the legacy media were related to different countermedia actors and fake news phenomenon in addition to media transparency and truthfulness in journalism. The first set of keywords in MV-lehti were related to the terms which $M V$-lehti used in referring to the journalistic media. After the preparatory search, we assessed samples of the resultant documents qualitatively and removed keywords that produced large amounts of irrelevant stories from the legacy media. For example, the word 'transparency' (läpinäkyvyys in Finnish) produced articles about transparent clothes and transparency in many other professional fields like flight safety and business. In MV-lehti, we also found and added more words related to the mainstream media. The second round, which we refer to as the formation of the research material, 
included 26 search clauses for the legacy media outlets and 10 for MV-lehti.

\begin{tabular}{|c|c|c|c|c|c|}
\hline MV-lehti & Yle & $\begin{array}{c}\text { Helsingin } \\
\text { Sanomat }\end{array}$ & Iltalehti & STT & Total \\
\hline 984 & 423 & 434 & 526 & 1034 & 3401 \\
\hline
\end{tabular}

Table 1: Article counts per media used in this study.

As Table 1 shows, we were left with 2417 articles from the selected legacy media outlets and 984 from $M V$-lehti. This material was further divided into five sub-categories for the legacy media (Figure 1) and three for $M V$-lehti (Figure 2). The categories were constructed qualitatively on the grounds of our pre-analysis of articles during the preliminary round. We chose the sub-category called "fake news phenomenon" ( $\mathrm{n}=807$ ) to serve as an analytical core for the legacy media. This included the stories, which mentioned the words 'fake news,' 'fake media,, 'post-truth', 'post-fact', 'countermedia', or 'alternative media. This dataset was supplemented with sub-categories identified by qualitative reading on the preliminary round, consisting of articulations of designated persons and countermedia outlets, together with mentions of Trump and fake news, Russia, and disinformation in the context of media. In our analysis, we focused on three sub-categories in MV-lehti, comprising any mentions of journalism $(n=411)$, of words referring to mainstream media $(n=268)$, and of the journalist Jessikka Aro $(n=305)$.

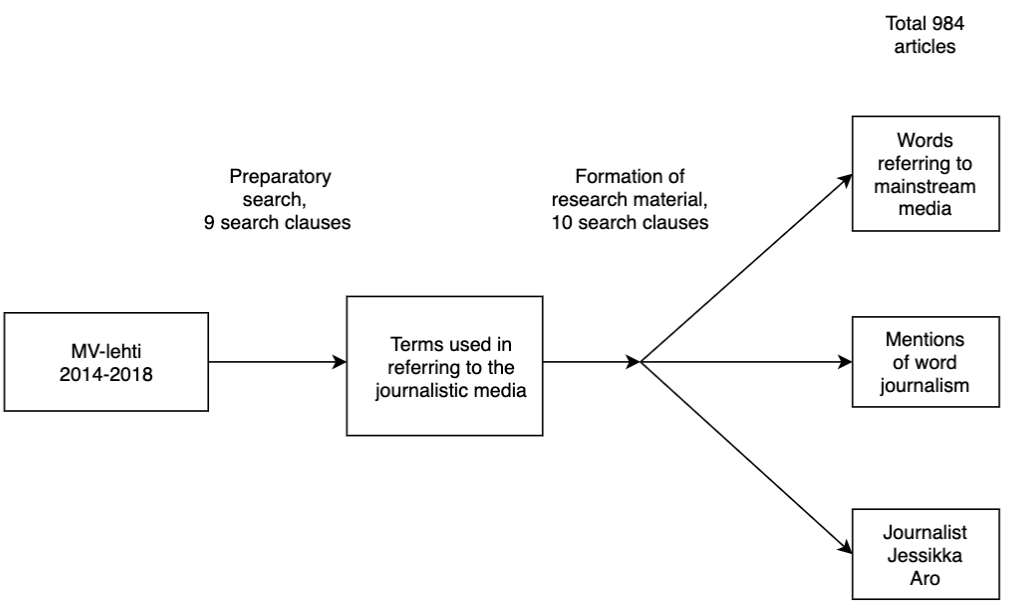

Figure 1: Downsampling process for MV-lehti dataset. 


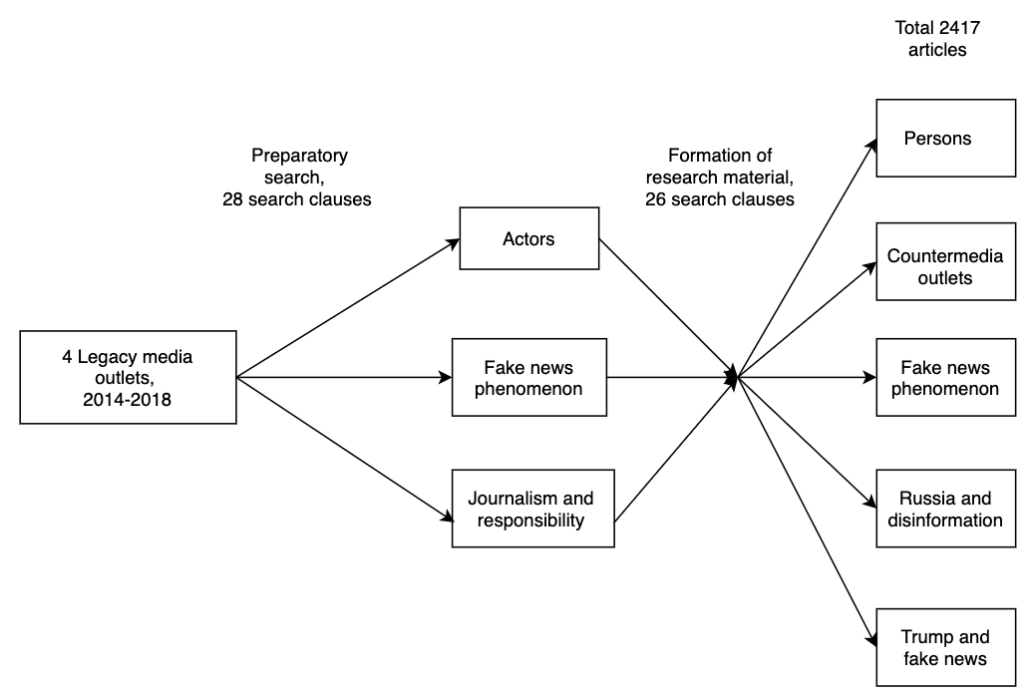

Figure 2: Downsampling process for the legacy media outlets.

Qualitative and quantitative methods were both used in our analysis. In addressing the prevalence of the fake news phenomenon in the Finnish media between 2014 and 2018, we employed computational frequency analysis to extract the occurrences of relevant discussions. The results of the frequency analysis enabled us to identify qualitative similarities and differences in the discussions. We supplemented the computational analysis with qualitative analysis to specify our findings. Additionally, to analyze boundary work in the chosen media we used qualitative methods. Following Gieryn (1983) we looked at the media actors' attribution of selected characteristics to their own publications and those of the other side. We focused on vocabulary, institutional reflection, demarcation practices, and ethos to make sense of the social boundaries between actors and to reconstruct how they distinguish between activities as journalism and non-journalism. These are not dependent on fixed characteristics, rather they should be understood as intertwined and overlapping, as, for example, institutional reflection and demarcation practices permeate the vocabulary and carry ideological implications. 


\section{Fake news phenomenon in Finnish media between 2014 and 2018}

\section{Case Finnbay: a precursor or a curiosity?}

In Finland, there were already traces of "valeuutinen" (fake news) in the blogosphere, used in conjunction with false information circulating in the media and the social web, from as early as 2011 (Järvinen, 2011). In our data, the idea of fake news as particularly problematic, surfaces in 2014. In April of that year, a site called Finnbay was called a "fake news site" (valeuutissivusto in Finnish) by the then Finnish Ambassador to Russia on Twitter (HS 6.4.2014). Finnbay was an English language site, which claimed to produce news on Finland. Interest in the site was triggered by a controversial story stating that Finland would cooperate with Russia no matter what the EU or the US would say. This occurred after the Russian annexation of Crimea, and the story was mostly based on Russian sources such as Itar-Tass (Finnbay 6.4.2014). After the Finnish Ministry of Foreign Affairs decided to investigate the site's activities, questions were raised over the "authenticity" of the site: the site reported a fictitious address and declared neither a corresponding editor, nor a business ID, as required in Finland (IL 6.4.2014; HS 7.4.2014). Later, the Finnish authorities declared that Finnbay did not disseminate harmful information on purpose (HS 10.4.2014). However, this encounter of "fake news" as a concept in Finnish media demonstrated the political nature of discussions about new media in a hybrid media space.

Finnbay was not the first news-media-like site to be accused of disseminating problematic information in Finland. Before "fake news" was articulated in a contemporary context, a site called Magneettimedia (Magnet Media) had gained media attention because of its conspiracist writing, vaccination criticism, and promotion of alternative medicine and pseudoscience (see Yle 8.12.2011; STT 27.3.2013). Initially, Magneettimedia was distributed only in print form, primarily in regions of Northwestern Finland, before going online in $2010 .^{2}$ It has a profile that is distinct from $M V$-lehti, although its stories have been frequently published by them; they are commonly regarded as the most prominent countermedia actors, and are described by Heikkilä and Väliverronen (2019) as "the public enemies of institu- 
tional journalism in Finland." Compared to these actors, Finnbay is a curious case. It echoes elements found in later discussions, including the lack of transparency in publishing and its connections to Russia, but it is now somewhat forgotten as the site was later shut down.

\section{The triangle: Countermedia, Trump, and Russian disinformation}

Our research indicates that domestic countermedia sites were only one of three main facets to the media discussion on fake news between 2014 and 2018. The other two were stories related to Donald Trump and his relentless friction with the media, and the Russian spread of disinformation. These three are not uniform. They each have their own particular characteristics, but they also represent different phases in Finnish media discourse on fake news. Qualitatively speaking, the cases of Russia and disinformation, as well as the one on countermedia actors, are more complex - and arguably more representative of the Finnish context - but quantitatively, Trump-related stories dominated the media discourse on fake news.

The timeline and prevalence of these phenomena can be seen in the three graphs below. They indicate how the so-called fake news phenomenon (blue line) ${ }^{3}$ was covered or made reference to, in Finnish media texts. In addition, the graphs show how the volume of stories related to the three different contexts developed over the research period. For example, the appearance of Finnbay is clearly visible from the first graph, as all the earliest fake news-related stories in 2014 were tied to this one affair. After Finnbay there are few mentions of Magneettimedia and MV-lehti until the second half of 2015. Heikkilä and Väliverronen (2019) date serious journalistic interest in $M V$-lehti to early Spring 2015 when $M V$ had published detailed stories on a (then alleged) case of rape, which pushed their readership up. Nevertheless, in our data, broader journalistic interest in $M V$-lehti only surfaced later, at the end of 2015, and stayed relatively stable until the end of 2016. 


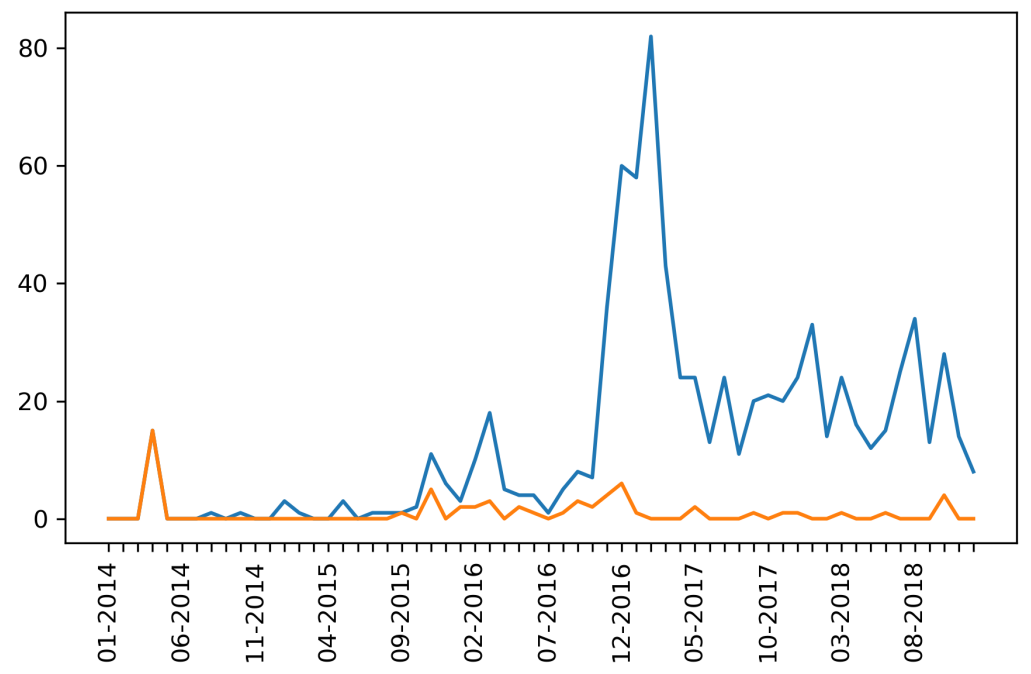

Graph 1: Weekly article frequencies of legacy media outlet articles containing the fake news phenomena dataset (blue line) and a subset with search words "MV-lehti" or "Magneettimedia" or "Finnbay" (orange line).

Notwithstanding this, the drastic increase in fake news-related content in Finnish legacy media occurred from approximately autumn 2016. This was almost entirely tied to the language used by the then presidential candidate Donald Trump and its subsequent reportage by the media. Graph 2 shows how Trump-related stories dominated the discussion on fake news throughout our period of research. Trump's frequent use of the labels "fake news" and "fake media" to address legacy media clearly permeated also Finnish media discourse. Boczkowski \& Papacharissi (2018) stress that despite the deep historical roots of the tensions between Trumplike politics and the media, social media brought a new dimension to the equation. Our data also shows how stories covering the fake news phenomenon often include mentions to Twitter, Facebook, and other social media outlets. This resulted, in the internet, social media, and the hybridization of the media system, functioning as a cross-cutting context in the coverage of the fake news phenomenon. 


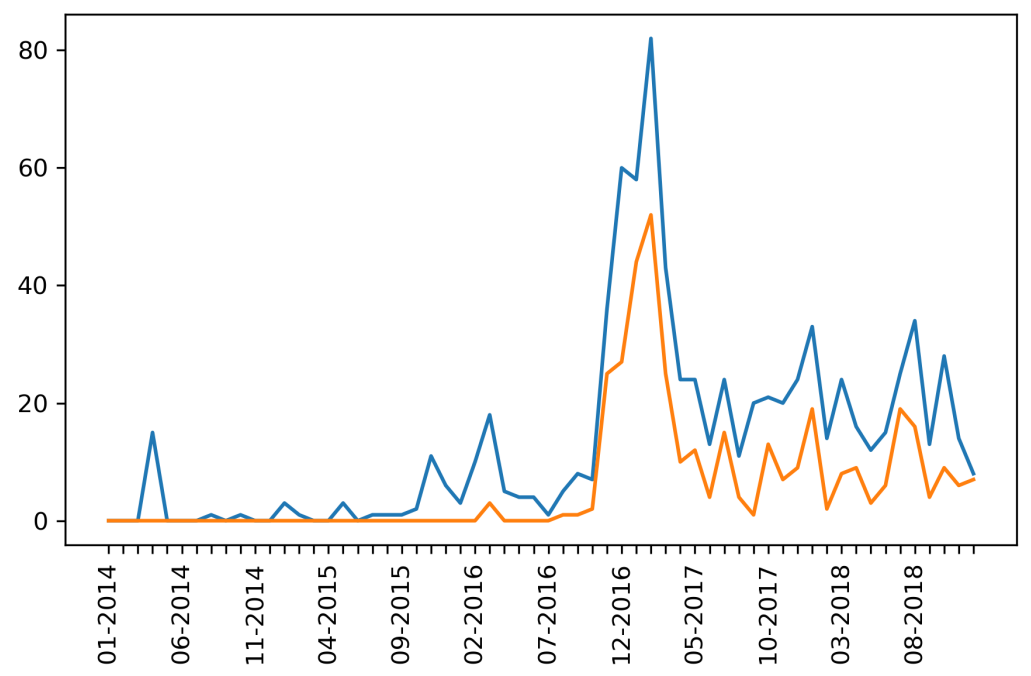

Graph 2: Weekly article frequencies of legacy media outlet articles containing the fake news phenomena dataset (blue line) and a subset with the search word “Trump" (orange line).

The third facet, the case of Russia, is interesting because Russia's disinformation campaigns have been connected to both the 2016 US presidential elections and Finnish countermedia. However, in our data, this case offers a distinct twirl to Finnish media's discourse on fake news, in the context of emerging stories on Russia's hybrid strategy and propaganda campaigns in the aftermath of the annexation of Crimea, escalating war in Ukraine, and the shooting down of the plane MH-17 (see Graph 3). Finnish legacy media were slow to react to the pace of events in Ukraine, as the media struggled to name and define the actors and dismantle pre-formulated Russian metanarratives (Innola \& Pynnöniemi, 2016, pp. 167-169). The peaks at the end of 2014 and early 2015 are related to the intensified reporting of Russian activities on different fronts, with the media using terms like "information war" (HS 19.1.2015), "hybrid warfare" (Yle 28.1.2015), and "Putin's propaganda" (IL 27.1.2015). This gradual shift was akin to the 'scales falling from the media's eyes' as they tried to come to terms with Russia's conduct in a new media environment. 


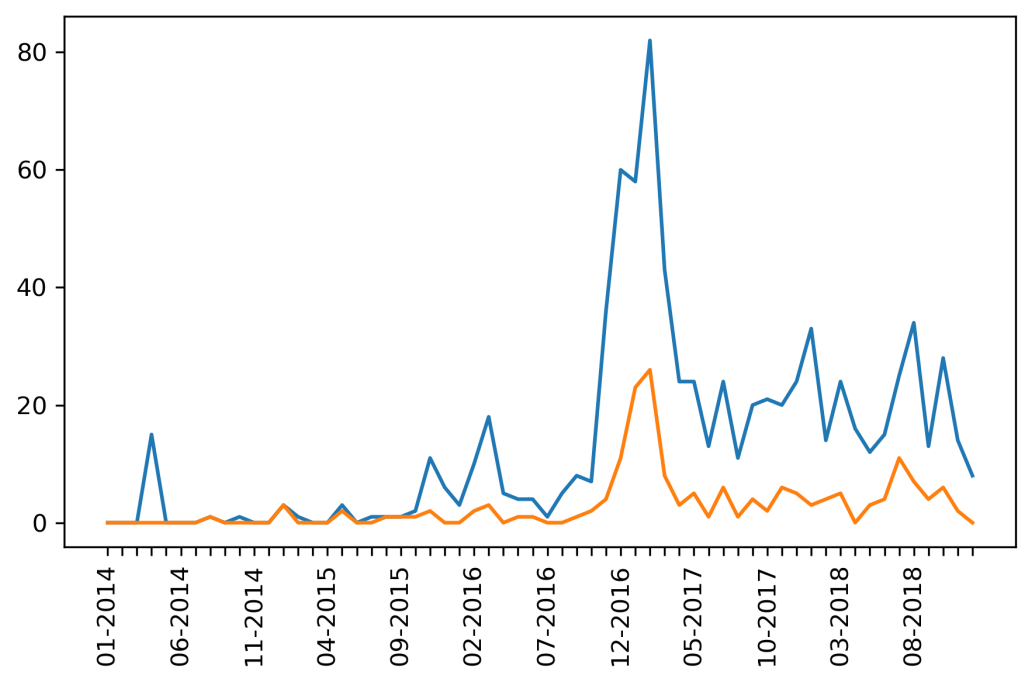

Graph 3: Weekly article frequencies of legacy media outlet articles containing the fake news phenomena dataset (blue line) and a subset with search words "Russia" and "media" (orange line).

The reporting on Russian actions in early 2015 was followed by a reportage series on a Russian "troll factory," the IRA, and the extent of Russia's online propaganda on Yle (Yle 18.2.2015a; Yle 18.2.2015b; Yle 19.5.2015, conducted mainly by journalist Jessikka Aro. In retrospect, this series became symbolically significant, as Aro herself became a victim of a systematic smear campaign and severe harassment (see Heikkilä \& Väliverronen, 2019; Hiltunen, 2017). The importance of her case was illustrated by the editors-in-chief's statement of 2016, which declared that journalists will not be silenced by abuse (Yle 1.3.2016). The founder of $M V$-lehti Ilja Janitskin was later accused - and found guilty in the district court before his death - of, amongst other charges, aggravated defamation (Yle 18.10.2018). We conducted a search with the name "Jessikka Aro" in our MV-lehti data which resulted in with 305 hits, meaning she was mentioned approximately twice a week on $M V$ between early 2015 and early 2018. 


\section{Boundary work in the Finnish mediasphere}

The content on Finnish legacy media and MV-lehti offers an interesting juxtaposition, as the extant literature suggests that these actors are in many ways incompatible yet intertwined. For instance, Toivanen et al. (2021) have noted how MV-lehti interacts with the legacy media through remediation of content. In addition, it is well documented how journalists default to defensive positions and retreat to their enduring values in the face of outside or institutional threats to journalism (see Carlson, 2015; Lewis, 2012; Deuze, 2005). Our research material - composed of media and journalism related content - yields an additional perspective to those of earlier studies. As shown in Figure 3, a more concise picture of the boundary work emerges through vocabulary, institutional reflection, demarcation practices, and ethos. Through an analysis that is divided between the two, we highlight the distinctive features and characteristics of boundary work, to show how both similarities and differences emerge. We begin with $M V$-lehti, because in our timeline it appears as a challenger which prompted a reaction from the media, which manifested as an attempt to monopolize the field and protect its autonomy (see Carlson, 2015; Gieryn, 1983).

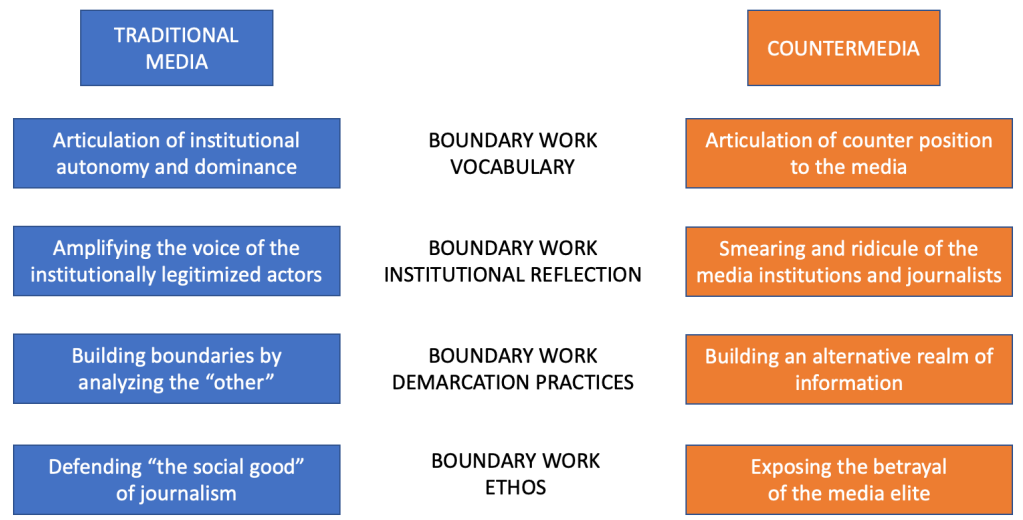

Figure 3: Analysis of the boundary work between the Finnish traditional media and countermedia. 


\section{Boundary work in MV-lehti: Exposure of political bias and betrayal of the media elite}

The various names and descriptions conferred upon journalistic media in $M V$-lehti's vocabulary can clearly be interpreted as boundary work that illuminated different aspects of their opposition to, or contempt for, their 'adversary'. There are several renditions of mainstream media, with the term prefixed by terms such as lying, deceitful, and distorting (MV 29.11.2015; MV 27.9.2016; MV 7.12.2017). The media itself is reduced to simpleton media, agenda media, and a fairly Finnish version of social justice warrior media, suvakkimedia (MV 2.8.2015; MV 11.5.2016; MV 21.1.2017). In a rhetorical move reminiscent of Trump, the term fake media was turned against traditional media. In this sense, the verb use was critically important. For example, when searches such as "mainstream media AND lies," and "mainstream media AND falls silent" were used, they produced 97 and 52 hits respectively in our data.

In terms of boundary work, the language in $M V$-lehti was constructed to articulate its counter position and to challenge traditional media's rationale and authority. This was done by depreciating, ridiculing, and smearing the media, media work and media professionals (echoing the case of Jessikka Aro). The practice was evident in cases where writers denounced journalists in affective terms: there were references to fanaticism (MV 2.5.2016) and hystericism (MV 16.3.2016) as well as fussing (MV 14.2.2018) and crying (MV 30.3.2016). Despite this, a significant portion of journalism and media-related statements were targeted on journalism as an institution. The Finnish Council on Mass Media, journalism's ethical codes and the Finnish editors-in-chief statement of 2016, all serve in MVlehti as symbols for the legacy media's biased foundations.

In our analysis, $M V$-lehti not only built boundaries as a counter actor, but also fashioned a secondary seam in which writers articulated the site as an alternative, a supplement, or a corrective to traditional mainstream news media (Holt et al., 2019). The writers ${ }^{4}$ themselves underlined the independence of MV-lehti as a publisher when they called it independent media, or independent citizen media (see MV 24.2.2016; MV 5.3.2016.). The emphasis on independence here is suggestive that the legacy media are non-independent, or biased. There are strong suggestions of political bias, which is seen in the 
media's tendencies to lean left (also radical left and green-left) or to promote cultural liberalism and multiculturalism (MV 9.10.2015; MV 2.3.2016a; MV 27.9.2016). There was also the alleged bias of practices. The whole new media ecosystem they represented, was suggested to have grown because the media has failed the people, by ignoring themes such as immigration-related problems which they suggested were left unreported by the mainstream media (see MV 12.1.2016; MV 15.2.2016; MV 2.3.2016b). For instance, Finnish media do not traditionally publish the names of people who are suspected of crimes, so when MV-lehti publishes names and details of these alleged crimes, they offer an alternative channel of information.

The aspiration to build an alternative realm of information can be depicted as a demarcation practice, although the borders with the media remained somewhat blurred. $M V$ 's ambiguity to journalism is palpable in the case of investigative journalism. Three distinct speech repertoires addressed investigative journalism in our data. First, there was the ridicule which typically referred to bad or trivial journalism or just the stupidity of journalists and their institutions (MV 20.9.2016). Secondly, the investigative journalism that the traditional media ought to be doing, but they were not (MV 31.5.2016), and thirdly, the investigative reporting MV-lehti was doing by exposing the so-called truths of immigration (MV 1.3.2016). While journalism as an institution is mostly deprecated, journalism was not argued to be completely corrupt. There were two cases in which journalists are thanked by name for doing proper investigative reporting in covering cases of Finnish corruption. These were certainly outliers, but it is nonetheless interesting how a departed journalist is generously thanked for her earlier award-winning work when the site expressed condolences to her family and relatives (MV 2.6.2016).

Nevertheless, there are strands of conspiracist thinking in $M V$ lehti's opposition to the media, and it is evident in the ethos of $M V$ 's boundary work that it stems from a desire to expose the betrayal of the media elite. $M V$-lehti, and its counterparts, suggest that they are lifting the veil of lies woven by corrupt elites (see Pyrhönen \& Beauvois, 2020), which can be seen as a strategy to give the impression that they represent the legitimate power and moral authority of the people (see Norris \& Inglehart, 2019). As Ylä-Anttila (2018) writes, conspiracist framing "should be understood as an absolutist orientation to power and democracy, one which divides the world into good 
and evil." In this sense, $M V$-lehti's conspiracism is tribalist; it stands against all knowledge-producing institutions like the free press, academia, and expert communities within government (see Muirhead \& Rosenblum, 2019). Hence it is not surprising that MV-lehti and its writers lambasted traditional media for a smear campaign - even a "war" (MV 23.11.2016) and a "witch hunt" (MV 25.10.2017) - which they perceived in journalists' repeated use of the term "fake media" as well as in journalistic coverage of the background and activities of those behind countermedia.

\section{Boundary work in the Finnish media: The institution sending a message}

$M V$-lehti's suggestion of a smear campaign was not entirely without foundation. The primary reaction to the rise of $M V$ and the whole fake news phenomenon in Finland has been reminiscent of the media's tendency to raise its guard in the face of opposition (see Heikkilä \& Väliverronen, 2019). This kind of general reaction can be seen in our data, and in its most quintessential form, it is very ceremonial. From the perspective of vocabulary, the central feature of this type of writing was to assert that $M V$-lehti and its counterparts were unequivocally "fake news" (valeuutinen) or "fake media" (valemedia). There was little or no room for conceptual contingency or leeway on the nature of these antagonistic actors, and the term fake news was deployed here as "a baseball bat to undermine the opponent's descriptions of reality" (Holt, 2020, p. 59). Furthermore, countermedia actors were depicted as profit-making and click-baiting cynics, who posed a threat to both public discourse and the civility of politics (see IL 1.11.2015).

In particular, the media's articulation of institutional autonomy and dominance emerged in two kinds of instances. The first was the statement from the editors-in-chief, which broadly covered all four examined media - each of them published at least three stories on it (including the original text). The second instance was the news written at the time of the appointment, or nomination, of prominent media figures such as the heads of the Council of Mass Media and public broadcaster Yle. These news stories, or interviews, were used as an opportunity to raise the institutional importance of journalism for society at large, with a tone of ceremonial speech that sought to (re)affirm the importance of journalism to democracy and to fun- 
damentally distinguish it from antagonistic outsiders. The language is uniform regardless of the speaker, which makes it safe to assume their basic stance to countermedia is widely shared amongst the journalistic community. Journalists writing the stories did not confront this stance, rather they amplified the voice of the legitimized actors. The basic attitude was, these "fake sites" (valesivustot) exploit journalistic credibility, yet publish unverified, or false, information without "seeking truth." It was noted, however, that some interviewees did ponder journalistic practices when they spoke of the media's self-regulation along with the importance of accountability and corrections. (See HS 2.11.2015; HS 4.11.2015; Yle 22.4.2016; Yle 6.2.2017; STT 17.4.2018.)

While the designation "fake media" in the context of countermedia actors was frequent, and its use rarely explained (HS 1.3.2016), not all the stories in traditional media described MV-lehti as being fake. Countermedia actors tended to be covered with greater nuance when research and polls were being reported (STT 14.11.2017), journalists' own analysis was published (Yle 1.11.2015d), or interviews with experts or researchers (Yle 1.11.2015a) as well as countermedia readers and actors were explored. In these stories, the concept of fake news was usually unpronounced or problematized, which meant both expressions "countermedia" (vastamedia) and "alternative media" (vaihtoehtomedia) were used. The media did interview the so-called other side whilst seeking to understand the logic behind the consumption (Yle 1.11.2015b; IL 24.9.2016) and production (Yle 1.11.2015c; Yle 5.2.2016) of countermedia content. This kind of reporting is linked to the professional core of journalism, but much like other examples we have pointed to, can also be described as boundary work. This resembles Gieryn's (1983) idea of the monopolization of professional authority and resources by excluding rivals. In this instance, journalists probed and explained the boundaries of different kinds of content production to the audience, and conspicuously depicted countermedia actors as "the other."

The ethos in Finnish media's boundary work stems from a defense of journalism as "the social good" as part of a wider media assertion of their own importance to democracy. Simultaneously, the media suggests to the audience that this social good, protected by ethical standards and practices, stands in opposition to the 'social bad' of distributing false information. This is also present in media reports of 
the court cases centered on countermedia actors, the media institutions, and reporter Jessikka Aro. Although not all of these stories represented $M V$ as fake media, there was an emphasis on the transgressions of the defendants and the harmfulness of their activities. In the context of the household reporting of a judicial case, there was special interest in MV-lehti and its founder Ilja Janitskin as "the other."

\section{Discussion}

We considered a period when the media landscape has been in turmoil. From 2014 to 2018 countermedia website $M V$-lehti was a thorn in the side of Finland's legacy media. It was frequently berated for disseminating false information and commonly designated, rather simplistically, as fake media. Because of the strong institutional and societal position of legacy media in Finland, there was a certain asymmetry to the relationship between them. While $M V$ had a relentless interest in the media - representing itself as David to the legacy media's Goliath - for journalists, the countermedia was part of a bigger change in the information environment. We have shown how the fake news discourse in Finnish media has been dominated by three partially separate realms: countermedia, Donald Trump and his accusations about the media, and Russia and disinformation.

After conceptualizing boundary work, we considered the ways in which writers defined "the hows and whys" of their own work and how they described the other. According to Gieryn (1983) boundary work should be seen as a practical problem with ideological implications. What is common to both the legacy media and countermedia, is the representation of the other as an ideological or a cynical actor, whereas one's own work, its core ethos, is presented as that which arises more from noble ideals and practices or the needs of the people. This, of course, is one way to fortify one's own boundaries whilst simultaneously using reductive vocabulary to define the other.

Thus, we found that qualitative differences to actors' ideological positioning were nested within general boundary work. For example, journalists in traditional media defended the institution of journalism almost uniformly: it's not about certain media, but the media, its institutions, and the commonly recognized journalistic practices and media ethics. In both Gieryn's (1983) and Carlson's (2015) terms, 
professional journalists both demarcated the monopoly of the institution in news publishing as well as defended the autonomy and professional activities of journalism whilst excluding $M V$-lehti as a non-professional troublemaker. While the media were keen on the manifest importance of journalism to democracy, they paid minimal attention to the ambiguousness, historically changing, contextually variable, internally inconsistent, and sometimes disputed nature of it. Arguably, this could be representative of the Northern European democratic-corporatist media system (Hallin \& Mancini, 2004), characterized by a particularly strong formal organization of the profession of journalism. In Finland, trust in legacy media is comparatively high (Newman et al. 2020, 14), and polarization (in connection with media use) is relatively weak in Scandinavia (see Dahlgren 2021). It may be that this strong societal adhesion to traditional media thwarts more open and nuanced public discussion on issues like transparency, accuracy, and ideology in its institutions and actors.

We argue that our findings on the nature of $M V$ 's boundary work are a significant contribution to the extant scholarship and wider public discussions on the nature of countermedia, or alternative, media (see Tuomola, 2021; Holt et al., 2019; Nygaard, 2019; Ylä-Anttila et al., 2019; Brinkschulte \& Frischlich, 2018). We have shown, how MV-lehti had the qualities of both a counter actor (to that dominated by the so-called elite) and a constructor of an alternative realm of information. Therefore, both countermedia and alternative media are valid terms, yet they remain imperfect in describing an actor like $M V$-lehti. In our reading, $M V$-lehti and its writers have a complicated relationship with journalism. For the most part, they denounced journalistic institutions and ridiculed journalists, which can be seen as a feature of an antagonistic challenger to the legacy media (see Harcup, 2005; Figenschou \& Ihlebæk, 2019; Mayerhöffer, 2021). Still, they exploited the journalistic form, and in some cases referred to their own work as investigative journalism. More attention should be given to this relationship, on the basis that countermedia work in $M V$-lehti can in our reading be seen as much as a kind of pseudo-journalistic publishing, as it is - at least partly - a form of non-journalism (see also Schudson, 2020, p. 13; Kovach \& Rosenstiel, 2014, p. 18). This is reminiscent of the deliberation about demarcation problems in science (see Hansson, 2011). Similar to pseudo-scientific ventures in relation to science, countermedia actors have sought to distort the tradi- 
tional perceptions of journalism and the ideals related to it. This is a timely and ongoing discussion, as the boundaries are more complex in journalism than in science, and many scholars want to move past binary distinctions between the legacy media and its interlopers or alternatives (see Eldridge II, 2019; Harcup, 2013, p. 9; Rauch, 2016).

Finally, academic studies on fake news and the disinformation conundrum have seen a marked emphasis on problematizing the designation of the phenomena, as well as the criticism of the political and journalistic treatment of the problem (see Farkas \& Schou, 2020; Egelhofer \& Lecheler, 2019; Tandoc et al., 2018). This strand of research is singularly important, but, as we have pointed out, themes like countermedia, Trump's accusations on the media, and Russia and disinformation are deeply connected or intertwined in public discussions. Consequently, studying these connections remains more than pertinent. Drawing directly on our findings, we strongly suggest that greater attention be given to the nature of the boundary work, and the positioning of the Finnish media with respect to international politics in the future. An in-depth qualitative analysis of stories mentioning Trump and Russian hybrid campaigns may not only broaden the view of boundary work and the media's fake news discourses but also account for Finnish media's understanding of Finland's geopolitical position. Likewise, from a comparative perspective, this article opens options for different research compositions to understand our findings relative to other media systems and time frames. A historical perspective - a broader view of the demarcation of journalism in the way our analytical framework draws from the work of Gieryn (1983) - might be worthwhile. Our results could then be juxtaposed with other "critical incidents" in media history - and in different countries - such as discussions on citizen journalism in the 1990s or the changes in the public sphere in the 1960s to understand journalists' ongoing struggle for authority.

\section{NOTES}

1 Most researchers have used the concept countermedia to describe $M V$ lehti, so we follow this tradition without undermining the importance of other conceptualizations. What is relevant is that sites like $M V$-lehti combine facts with fiction and rumors, oftentimes intentionally blurring the lines or spreading lies, other times cherry-picking, coloring and framing 
information to promote a right-wing or radical anti-immigrant agenda. (Tuomola et al. 2021; Ylä-Anttila et al. 2019; Ylä-Anttila 2017.)

2 To get a concise picture of the emergence of fake news phenomenon we included all mentions of Magneettimedia in the researched legacy media outlets from years 2010-2013 to the research material.

3 The mentions of fake news phenomena in four researched media with the words fake news, fake media, post-truth, post-fact, countermedia, alternative media.

4 Only a proportion of the news stream is written by $M V$ 's own writers, as they also circulate texts from other sites as well as bloggers, forum writers, readers and social media users postings.

\section{REFERENCES}

Aral, S. (2020). The Hype Machine. How Social Media Disrupts Our Elections, Our Economy and Our Health - and How We Must Adapt. HarperCollins.

Beckett, C. (2017). Fake news: the best thing that has happened to journalism. London School of Economics and Political Science.

Bell, E. J., Owen, T., Brown, P. D., Hauka, C. \& Rashidian, N. (2017). The Platform Press: How Silicon Valley Reengineered Journalism. Tow Center for Digital Journalism, Columbia University. https://doi.org/10.7916/ D8R216ZZ

Boczkowski, P. J. \& Papacharissi, Z. (2018). Introduction. In P. J. Boczkowski \& Z. Papacharissi (eds.), Trump and the media (pp. 1-6). MIT Press.

Bradshaw, S. (2019). Disinformation optimised: gaming search engine algorithms to amplify junk news. Internet Policy Review, 8(4), 1-24. https:// doi.org/10.14763/2019.4.1442

Brinkschulte, F. \& Frischlich, L. (2018). Fake news? Disinformation in the age of digital media. WWU University of Münster Online. Retrieved from: https://www.uni-muenster.de/news/view.php?cmdid=9428

Carey, J. W. (1997). Afterword: The Culture in Question. In E. S. Munson and C. A. Warren (eds.), James Carey: A Critical Reader (pp. 308-340). University of Minnesota Press.

Carlson, M. (2016). Metajournalistic Discourse and the Meanings of Journalism: Definitional Control, Boundary Work, and Legitimation. Communication Theory, 26(4), 349-368. https://doi.org/10.1111/comt.12088

Carlson, M. (2015). Introduction: The many boundaries of journalism. In M. Carlson \& S. C. Lewis (eds.), Boundaries of Journalism. Professionalism and Participation (pp. 1-18). Routledge.

Chadwick, A. (2017). The Hybrid Media System: Politics and Power. Second 
Edition. Oxford University Press.

Dahlgren, P. M. (2021). Media Echo Chambers: Selective Exposure and Confirmation Bias in Media Use, and its Consequences for Political Polarization. University of Gothenburg.

Deuze, M. (2019). What Journalism Is (Not). Social Media + Society. https:// doi.org/10.1177/2056305119857202

Deuze, M. \& Witschge, T. (2018). Beyond journalism: Theorizing the transformation of journalism. Journalism, 19(2), 165-181. https://doi. org/10.1177/1464884916688550

Deuze, M. (2005). What Is Journalism? Professional identity and ideology of journalists reconsidered. Journalism, 6, 442-64. https://doi. org/10.1177/1464884905056815

Egelhofer, J. L. \& Lecheler, S. (2019.) Fake news as a twodimensional phenomenon: a framework and research agenda. Annals of the International Communication Association, 43(2), 97-116. https://doi.org/10.1080/2380 8985.2019.1602782

Eldridge II, S. (2019). Where Do We Draw the Line? Interlopers, (Ant)agonists, and an Unbounded Journalistic Field. Media and Communication, 7(4), 8-18. https://doi.org/10.17645/mac.v7i4.2295

Farkas, J. \& Schou, J. (2020). Post-truth, Fake News and Democracy. Mapping the Politics of Falsehood. Routledge.

Figenschou, T. U., \& Ihlebæk, K. A. (2019). Media Criticism from the FarRight: Attacking from Many Angles. Journalism Practice, 13(8), 901-905. https://doi.org/10.1080/17512786.2019.1647112

Gelfert, A. (2018). Fake News: A Definition. Informal Logic 38(1), 84-117.

Gieryn T. F. (1999). Cultural Boundaries of Science. University of Chicago Press.

Gieryn, T. F. (1983). Boundary-work and the demarcation of science from non-science: Strains and interests in professional ideologies of scientists. American Sociological Review, 48(6), 781-795.

Haller, A., Holt, K. \& de La Brosse, R. (2019). The 'other' alternatives: Political right-wing alternative media. Journal of Alternative \& Community Media, 4(1), 1-6. https://doi.org/10.1386/joacm_00039_2

Hallin, D. C. \& Mancini, P. (2004). Comparing media systems: Three models of media and politics. Cambridge University Press.

Hansson, S. O. (2011). Science and Pseudo-Science. In E. N. Zalta (ed.), The Stanford Encyclopedia of Philosophy. Stanford University. Retrieved from: plato.stanford.edu/archives/sum2017/entries/pseudo-science/

Harcup, T. (2005). “I'm Doing This to Change the World”: Journalism in 
Alternative and Mainstream Media.' Journalism Studies, 6(3): 361-374. https://doi.org/10.1080/14616700500132016

Harcup, T. (2013). Alternative Media, Alternative Voices. Routledge.

Heft, A., Mayerhöffer, E., Reinhardt, S. \& Knüpfer, C. (2019). “Beyond Breitbart:

Comparing Right-Wing Digital News Infrastructures in Six Western Democracies." Policy and Internet, 12(1), 20-45. https://doi.org/10.1002/ poi3.219.

Heikkilä, H. \& Väliverronen, J. (2019). Media-accountability in the Era of Fake News: Journalistic boundary work and its problems in Finland. In T. Eberwein, S. Fengler \& M. Karmasin (eds.), Media Accountability in the Era of Post-Truth Politics: European Challenges and Perspectives. Routledge.

Hermida, A. (2015) Nothing But the Truth: Redrafting the Journalistic Boundary of Verification. In M. Carlson and S. C. Lewis (eds.), Boundaries of Journalism (pp. 37-50). Routledge.

Hiltunen, I. (2017) Trouble in paradise? Self-censorship, outside interference and harassment of journalists in Finland. Media Asia, 44(1), 66-70. https://doi.org/10.1080/01296612.2017.1374632

Holt, K. (2020). Right-wing alternative media. Routledge.

Holt, K., Ustad Figenschou, T. \& Frischlich, L. (2019). Key Dimensions of Alternative News Media. Digital Journalism, 7(7), 860-869. https://doi.org $/ 10.1080 / 21670811.2019 .1625715$

Holt, K. (2018). Alternative Media and the Notion of Anti-Systemness: Towards an Analytical Framework. Media and Communication, 6(4), 49-57. http://dx.doi.org/10.17645/mac.v6i4.1467

Hopp, T., Ferrucci, P. \& Vargo, C. J. (2020). Why Do People Share Ideologically Extreme, False, and Misleading Content on Social Media? A Self-Report and Trace Data-Based Analysis of Countermedia Content Dissemination on Facebook and Twitter. Human Communication Research, 46(4), 357384. https://doi.org/10.1093/hcr/hqz022

Howard, P. N. (2020). Lie Machines. How to Save Democracy from Troll Armies, Deceitful Robots, Junk News Operations, and Political Operatives. Yale University Press.

Innola, E. \& Pynnöniemi, K. (2016). Finland and Russia's Metanarratives on the Conflict in Ukraine. In K. Pynnöniemi \& A. Rácz (eds.), Fog of falsehood. Russian strategy of deception and the conflict in Ukraine. FIIA Report No. 45. The Finnish Institute of International Affairs.

Järvinen, P. (2011, August 18). Älä usko Twitteriä [Blog post]. Retrieved from: https://pjarvinen.blogspot.com/2011/08/ala-usko-twitteria.html 
Kovach, B. \& Rosenstiel, T. (2014). The Elements of Journalism: What Newspeople Should Know and the Public Should Expect. 3rd edition. Crown.

Lazer, D. M. J., Baum, M. A., Benkler, Y., Berinsky, A. J., Greenhill, K. M., Menczer, F., . . Zittrain, J. L. (2018). The science of fake news. Science, 359, 1094-1096. https://doi.org/10.1126/science.aao2998

Levendusky, M. S. (2013). Why Do Partisan Media Polarize Viewers? American journal of political science, 57(3), 611-623. https://doi.org/10.1111/ ajps.12008

Lewis, S. C. (2012). The Tension Between Professional Control and Open Participation. Information, Communication \& Society, 15(6), 836-866. https://doi.org/10.1080/1369118X.2012.674150

Mayerhöffer, E. (2021). How do Danish right-wing alternative media position themselves against the mainstream? Advancing the study of alternative media structure and content. Journalism Studies, 22(2), 119-136. https:// doi.org/10.1080/1461670X.2020.1814846

Mourão, R. R. \& Robertson, C. T. (2019). Fake News as Discursive Integration: An Analysis of Sites That Publish False, Misleading, Hyperpartisan and Sensational Information. Journalism Studies, 20(14), 2077-2095. https:// doi.org/10.1080/1461670X.2019.1566871

Mohr, M. (2019, July 26). Surprisingly old words that seem contemporary. The Christian Science Monitor. Retrieved from: https://www.csmonitor.com/The-Culture/In-a-Word/2019/0726/Surprisingly-old-wordsthat-seem-contemporary

Muirhead, R. \& Rosenblum, N. L. (2019). A Lot of People Are Saying. The New Conspiracism and the Assault on Democracy. Princeton University Press.

Newman, N., Fletcher, R., Schulz, A., Andı, S. \& Kleis Nielsen, R. (2020). Reuters Institute Digital News Report 2020. Reuters Institute for the Study of Journalism.

Norocel, O. C., Saresma, T., Lähdesmäki, T., \& Ruotsalainen, M. (2020). Discursive Constructions of White Nordic Masculinities in Right-wing Populist Media. Men and Masculinities, 23(3-4), 425-446. https://doi. org/10.1177/1097184X18780459

Norris, P., \& Inglehart, R. (2019). Cultural Backlash. Trump, Brexit, and Authoritarian Populism. Cambridge University Press.

Nygaard, S. (2020). Boundary Work: Intermedia Agenda-Setting Between Right-Wing Alternative Media and Professional Journalism. Journalism Studies, 21(6), 766-782. https://doi.org/10.1080/1461670X.2020.1722731

Nygaard, S. (2019). The Appearance of Objectivity: How Immigration-Critical Alternative Media Report the News. Journalism Practice, 13(10), 1147- 
1163. https://doi.org/10.1080/17512786.2019.1577697

Pyrhönen, N., \& Bauvois, G. (2020). Conspiracies beyond Fake News. Produsing Reinformation on Presidential Elections in the Transnational Hybrid Media System. Sociological Inquiry, 90, 705-731. https://doi.org/10.1111/ soin. 12339

Rae, M. (2020). Hyperpartisan news: Rethinking the media for populist politics. New Media \& Society. https://doi.org/10.1177/1461444820910416

Rauch, J. (2016). Are There Still Alternatives? Relationships Between Alternative Media and Mainstream Media in a Converged Environment. Sociology Compass, 10(9), 756-767, https://doi.org/10.1111/soc4.12403

Schudson, M. (2020). Journalism. Why it matters. Polity.

Schudson, M. (2003). The Sociology of News. W. W. Norton \& Company.

Schulze, H. (2020). Who Uses Right-Wing Alternative Online Media? An Exploration of Audience Characteristics. Politics and Governance, 8(3), 6-18. https://doi.org/10.17645/pag.v8i3.2925

Singer, J. B. (2015) Out of bounds. Professional norms as boundary markers. In M. Carlson and S. C. Lewis (eds.), Boundaries of Journalism (pp. 21-36). Routledge.

Tandoc, E. C.; Jenkins, J. \& Craft, S. (2019). Fake News as a Critical Incident in Journalism. Journalism Practice, 13(6), 673-689, DOI: 10.1080/17512786.2018.1562958

Tandoc, E. C \& Jenkins, J. (2018). Out of Bounds? How Gawker's Outing a Married Man Fits into the Boundaries of Journalism. New Media \& Society, 20(2), 581-98. https://doi.org/10.1177/1461444816665381.

Tandoc E. C; Lim, Z. W. \& Ling, R. (2018). Defining “Fake News”. Digital Journalism, 6(2), 137-153. https://doi.org/10.1080/21670811.2017.1360143

Tandoc, E. C. (2018). Five ways BuzzFeed is preserving (or transforming) the journalistic field. Journalism, 19(2), 200-216. https://doi. org/10.1177/1464884917691785

Toivanen, P., Nelimarkka, M. \& Valaskivi, K. (2021). Remediation in the hybrid media environment: Understanding counter-media in context. New Media \& Society. https://doi.org/10.1177/1461444821992701

Tuomola, S. (2021). Who are you, the people? Nordicom Review, 42(S1), 51-65. https://doi.org/10.2478/nor-2021-0006

Välimäki, R., Seuri, O. \& Ristilä, A. (2021). Pseudohistoriaa Suomen muinaisista kuningaskunnista - Ongelmallisen tiedon kierto laitaoikeiston mediaekosysteemissä. Niin \& näin, 1/2021, 118-135.

Ylä-Anttila, T., Bauvois, G. \& Pyrhönen, N. (2019). Politicization of migration in the countermedia style: A computational and qualitative analysis 
of populist discourse. Discourse, Context and Media, 32, 1-8. https://doi. org/10.1016/j.dcm.2019.100326

Ylä-Anttila, T. (2018) Populist knowledge: 'Post-truth' repertoires of contesting epistemic authorities. European Journal of Cultural and Political Sociology, 5(4), 356-388. https://doi.org/10.1080/23254823.2017.1414620

Ylä-Anttila, T. (2017). The Populist Toolkit. Finnish Populism in Action 20072016. University of Helsinki. Publications of the Faculty of Social Sciences $59 / 2017$.

Zelizer, B. (1992). CNN, the Gulf War, and Journalistic Practice. Journal of Communication. 42(1), 66-81. https://doi.org/10.1111/j.1460-2466.1992. tb00769.x

\section{EMPIRICAL MATERIAL CITED}

Yle 8.12.2011. Yle. "J.Kärkkäisen Magneettimedialle vuoden Huuhaapalkinto", Yle.

STT 27.3.2013. STT. "Long Play: Ilmaislehden kirjoituksilla yhteys lääkekielteisyyteen", STT.

Finnbay 6.4.2014. FINNBAY. "Letter From FINNBAY Regarding Its Authority", Finnbay. Found on Internet Archive: https://web.archive.org/ web/20140409005450/http://www.finnbay.com/letter-from-finnbayregarding-its-authority/.

HS 6.4.2014. Halminen, L. "Suomen Venäjän-lähettiläs ja uutissivusto sanasodassa”, Helsingin Sanomat.

IL 6.4.2014. Ilta-Sanomat. "Suurlähettiläs IS:lle: Ulkoministeriö tekee selvitystä Finnbaysta", Iltalehti.

HS 7.4.2014. Hannula, T. “Kohusivusto Finnbayn edustaja ei vastaa - 'Hän pyysi, etten antaisi puhelinnumeroa", Helsingin Sanomat.

HS 10.4.2014. "STT-HS. Ulkoministeriö: Finnbayn tarkoitus ei ole ollut levittää vahingoittavaa tietoa”, Helsingin Sanomat.

HS 19.1.2015. Kauhanen, A-L. “Miten infosodassa puolustaudutaan?”, Helsingin Sanomat.

IL 27.1.2015. Dale, N. “Putinin propaganda menee läpi Venäjällä - 'Eri todellisuus kuin meillä", Iltalehti.

Yle 28.1.2015. Tapiola, P. “Tutkijat hybridisodankäynnistä: Sotia ei julisteta. Niihin liu'utaan", Yle.

Yle 18.2.2015a. Mäkeläinen, M. \& Aro, J. "Yle Pietarin trollitehtaalla - Näin Venäjän propagandaa rustataan kellon ympäri”, Yle.

Yle 18.2.2015b. Aro, J. \& Mäkeläinen, M. "Kioski Venäjän some-propagandan alkulähteillä - katso ennennäkemätön materiaali trollitehtaalta", Yle. 
Yle 19.5.2015. Aro, J. “Tältä Venäjän verkkopropaganda tuntuu - suomalaisia saatu uskomaan valheisiin", Yle.

MV 2.8.2015. Janitskin, I. “Suomalainen valtamedia todisti tänään kuinka se lukijoitansa kohtelee", MV-lehti.

MV 9.10.2015. MV. “Toimittaja: Media sensuroi maahanmuuttajarikollisuutta ja lobbaa homokulttuuria”, $M V$-lehti.

IL 1.11.2015. Mattila, M. "Väärät faktat ovat polttopulloja”, Iltalehti.

Yle 1.11.2015a. Koivuranta, E. "Julkisen keskustelun häirikkö" - Eliitin vastainen media heijastaa suomalaista herravihaa, Yle.

Yle 1.11.2015b. Mäntymaa, E. “Kansa on kyllästynyt manipulointiin, kontrolliin ja valehteluun' - tämän vuoksi MV-lehteä luetaan”, Yle.

Yle 1.11.2015c. Mäntymaa, E., Tuominen, S., Hurtta, A. \& Toivonen, J. "Holokausti on myytti ja muita väitteitä - näin toimii suomalainen vastamedia", Yle.

Yle 1.11.2015d. Mäntymaa, E., Tuominen, S., Hurtta, A. \& Toivonen, J. “Näin somehuhusta tulee "totta" - tarkastelussa kolme vastamedian uutista", Yle.

HS 2.11.2015. Koppinen, M. "Median vahtikoira saa uuden vetäjän: 'Tämä on hurja aika aloittaa tehtävässä"', Helsingin Sanomat.

HS 4.11.2015. Lehmusvesi, J. “Mediaetiikan uusi vartija Elina Grundström: 'Suomalainen sananvapaus on uhattuna valesivustojen takia", Helsingin Sanomat.

MV 29.11.2015. MV. "Karut tosiasiat mamutuksesta ja 'pakolais'tilanteesta”, MV-lehti.

MV 12.1.2016. T2/MV. “Usarikin yrittää häpäistä MV:tä - lukijat ilmoittavat kannattavansa", MV-lehti.

Yle 5.2.2016. Yle Uutiset. "Yle Perjantai haastatteli kiistellyn MV-lehden perustajaa", Yle.

MV 15.2.2016. Janitskin, I. “Oikeustieteen professori: 'Kansallismieliset piirit ovat pienet", $M V$-lehti.

MV 24.2.2016. T2/MV. "Yle-toimittajan huumeskandaali: saalistajista saalistetuiksi?", MV-lehti.

HS 1.3.2016. Junkkari, M. "Päätoimittajat tukevat parjauskampanjoiden kohteeksi joutuneita toimittajia - tästä kannanotossa on kyse”, Helsingin Sanomat.

Yle 1.3.2016. Yle. "Päätoimittajien kannanotto: Luotettavan median puolesta", Yle.

MV 1.3.2016. T3/MV. "Päätoimittajien vetoomus näyttää informaatiosodalta", MV-lehti.

MV 2.3.2016a. T2/MV. Tanskan yleisradion toimitusjohtaja: Poliittinen kor- 
rektius on kaapannut journalismin (video), MV-lehti.

MV 2.3.2016b. T3/MV. “Kuru: Näkökulma mediasodasta”, MV-lehti.

MV 5.3.2016. T2/MV. "Valtamedia syyttää kansalaisia omista valheistaan", MV-lehti.

MV 16.3.2016. Janitskin, I. “Miksi valtamedia hävisi taistelunsa?”, MV-lehti.

MV 30.3.2016. T9/MV. Suomen tiedetoimittajien liiton pääsihteeri iskee vihapuhetta ja sosiaalista mediaa vastaan, $M V$-lehti.

Yle 22.4.2016. Iikkanen, T. “JSN:n Elina Grundström: Laatujournalismi maksaa - valehtelu on ilmaista", Yle.

MV 2.5.2016. T2/MV. "Hesari herjaa rasisteiksi Tapanilan Rajat Kiinni! -mielenosoittajia!", $M V$-lehti.

MV 11.5.2016. T3/MV. "Parolan panssarimuseon panssarivaunut ovat heitteillä taivasalla - sinä voit auttaa, kun valtiota ei kiinnosta”, MV-lehti.

MV 31.5.2016. Janitskin, I. “Median salaliitto", MV-lehti.

MV 2.6.2016. MV. Tutkiva journalisti Annukka Roininen (YLE) - R.I.P., $M V$ lehti.

MV 20.9.2016. Janitskin, I. “Eläköön Pravda ja pölhöpopulismi! Suvaitsevaisto sai lopulta kaipaamansa 'marttyyrin', MV-lehti.

IL 24.9.2016. Egutkina, A. “Nyt puhuvat 'valtamediaan' pettyneet: 'Emme ole alamaisia, joita pitää valistaa”, Iltalehti.

MV 27.9.2016. T2/MV. “Rantanen: Luen MV-lehteä koska...”, MV-lehti.

MV 23.11.2016. Janitskin, I. "ANALYYSI: Valeuutisia ja "oikeita" uutisia”, $M V$ lehti.

MV 21.1.2017. T2/MV. "Ilja Janitskin: Miksi niin monet suomalaiset pelkäävät omaa maataan?”, MV-lehti.

Yle 6.2.2017. Junttila, J. “Päätoimittajayhdistyksen Arno Ahosniemi: 'Journalismissa virhe myönnetään ja oikaistaan”, Yle.

MV 25.10.2017. T102/MV. "Janus Putkonen: Valtamedian johtama noitavaino ja ylikansallisen eliitin kaksinaismoralismi oksettavat", MV-lehti.

STT 14.11.2017. Nikkilä-Kiipula, E. “Suurin osa uskoo tunnistavansa valheelliset uutiset", STT.

STT 17.4.2018. STT. "Ylen uusi toimitusjohtaja haluaa vahvaa yhteistyötä suomalaismedioille", STT.

MV 7.12.2017. T3/MV. "Punakaartilaistoimittelijatar Anni Saastamoisen valheuutinen Iltalehdessä”, $M V$-lehti.

MV 14.2.2018. T1004. "Nyt se on todistettu: Aamulehti unohtaa ulkomaisen raiskaajan nimen 77 tunnissa", $M V$-lehti.

Yle 18.10.2018. Yle. “Anti-immigrant agitator Ilja Janitskin gets 22-month jail sentence", Yle. 
HS 18.12.2018. Mäkinen, E. "MV-lehden valheet yhdistettynä Facebookin ahneuteen on otollinen kasvualusta vihalle", Helsingin Sanomat.

\section{OLLI SEURI}

Postdoctoral Researcher

Faculty of Social Sciences

Tampere University

olli.seuri@tuni.fi

\section{PIHLA TOIVANEN}

Doctoral Student

Department of Digital Humanities

University of Helsinki

pihla.toivanen@helsinki.fi

DOI: 10.7146/journalistica.v15i1.125038 